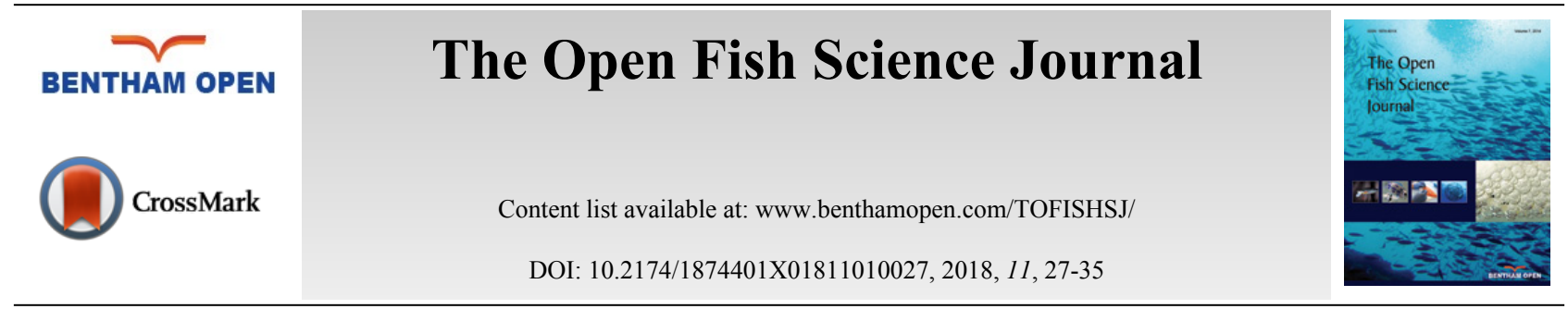

RESEARCH ARTICLE

\title{
Food Web Analysis of Jordanelle Reservoir, Utah, USA: Where Do All the Rainbows Go?
}

\author{
Joshua A. Verde* and Mark C. Belk \\ 4102 LSB, Department of Biology, Brigham Young University, Provo, UT84601, USA
}

Received: May 28, 2017

Revised: July 11, 2018

Accepted: July 24, 2018

\begin{abstract}
:
Background:

Reservoir communities in the intermountain west are typically dominated by a mix of introduced fishes. Due to the non-coevolved interactions present in these communities, energy flow and trophic interactions may not facilitate optimal growth and survival for all species. It is difficult to predict how well each species will survive in such novel communities. One such community is in Jordanelle Reservoir in northern Utah, USA. Recently, low survival and recruitment of stocked rainbow trout (Onchorhynchus mykiss) have been observed in Jordanelle Reservoir.
\end{abstract}

\section{Objective:}

We characterize the food web structure of the fish community in Jordanelle reservoir to infer competitive or predatory interactions that might lead to a poor return of stocked rainbow trout.

\section{Methods:}

We performed a stable isotope analysis on the fish community in Jordanelle Reservoir and carried out niche space analyses using the software package Stable Isotope Bayesian Ellipse (SIBER) in R.

\section{Results:}

Small rainbow trout exhibit high competitive overlap with brown trout (Salmo trutta), smallmouth bass (Micropterus dolomieu), and yellow perch (Perca flavescens). In addition, large brown trout and large smallmouth bass may feed heavily on small rainbow trout.

\section{Conclusion:}

Food web analysis suggests that rainbow trout encounter a highly competitive and potentially high predation environment in Jordanelle reservoir, leading to observed low return rates.

Keywords: Food web, Stable isotope analysis, Rainbow trout, Trophic level, Littoral energy pathway, Pelagic energy pathway.

\section{INTRODUCTION}

Reservoirs in the intermountain west are typically dominated by a mix of non-native fish introduced from elsewhere in North America or Europe for angling purposes [1 - 5]. The novel interactions among fish in these reservoirs can cause the food web to function in non-coevolved and unpredictable ways [6, 7]. Often, food webs in reservoirs are less stable than food webs in natural lakes with intact native species compositions [8]. Many aquatic systems have sizestructured interactions between species [9 - 11]. Ontogenetic niche shifts and mixed competition-predation interactions result in complex systems where a single species can fill several different niches depending on its life stage [12].

* Address correspondence to this author at the 4102 LSB, Department of Biology, Brigham Young University, Provo, UT 84601, USA., Tel: +1 (435) 669-7458; E-mail: joshverde@yahoo.com 
The evolutionary history of an introduced species interacts with local environmental and biotic conditions to increase potential complexities. These novel interactions can result in high levels of predation (top-down effects) or reduced amounts of energy flow up through the food web (bottom-up effects) [8, 13]. Given the complexity of aquatic ecosystems and the novelty of artificial reservoir communities, it is often difficult to determine what species combinations may lead to optimal growth and survival of target species.

In freshwater lentic systems, both top-down and bottom-up effects can influence the growth and population dynamics of fishes [14, 15]. Top-down effects are manifest as control of lower trophic levels by consumers and in freshwater systems, this is typically control of zooplankton or small fishes by larger predatory fishes [16, 17]. Bottomup effects are manifest as control of higher trophic levels by producers, where nutrient availability typically determines the productivity of phytoplankton and thus exerts control on zooplankton and fish occupying the trophic levels above [18]. In natural systems, both top-down and bottom-up forces can act simultaneously on community structure and function and effects can potentially be interactive $[19,20]$.

Rainbow trout (Oncorhynchus mykiss) are a highly sought after game fish and, as such, have been widely stocked for recreational fishing [21]. Jordanelle Reservoir, in central Utah, has been continuously stocked with rainbow trout since the impoundment was completed in 1992 and is currently stocked annually with rainbow trout at an average size of 217 mm (2012-2015, Utah Division of Wildlife Resources stocking report). The catch per unit effort for rainbow trout in Jordanelle reservoir was initially high after the reservoir filled and then reached an equilibrium at lower catch rates [22], possibly due to reservoir aging [23]. However, in recent years, the catch rate for rainbow trout has dropped further and the cause of this is not known [22, 24]. Introduced sportfish comprise the majority of the fish community in Jordanelle, with brown trout (Salmo trutta), rainbow trout, and smallmouth bass (Micropterus dolomieu) attaining the largest body sizes. The presence of these three top-level predators in Jordanelle reservoir suggests that competition for prey with brown trout and smallmouth bass may be responsible for the poor return on stocked rainbow trout. Alternatively (or additionally), small rainbow trout may sustain high amounts of predation from larger brown trout, smallmouth bass, and even cannibalism from large rainbow trout. To illuminate the likely contributing factors, we can employ a characterization of the food web in Jordanelle reservoir to reveal the mixed competition-predation interactions and clarify why stocked rainbow trout exhibit poor returns in catch rates.

Stable isotope ratios of carbon and nitrogen have been used to characterize food webs and trophic niche because they integrate an organism's diet into two simple, but informative variables [25]. Stable isotope ratios provide a timeintegrated measure of an organism's diet for a specific time-window [26]. The stable isotope ratio of nitrogen $\left(\delta^{15} \mathrm{~N}\right)$ is used to estimate the trophic level of an organism because it is enriched from prey item to predator by roughly $3-4 \%$ (parts per thousand) [27 - 29]. The stable isotope ratio of carbon $\left(\delta^{13} \mathrm{C}\right)$ is indicative of the source of carbon fixation (i.e., source of energy) [29 - 33]. In a lake ecosystem, the $\delta^{13} \mathrm{C}$ is useful to differentiate between pelagic and littoral carbon sources. Carbon fixed in littoral environments is enriched in $\delta^{13} \mathrm{C}$ relative to carbon fixed in the pelagic energy pathway [34].

To explore the problem of low return on stocked rainbow trout in Jordanelle reservoir we used stable isotope analysis to quantify the food web structure and determine the trophic niche of rainbow trout. Our objective was to explore possible top-down or bottom-up factors that may lead to low survival of stocked rainbow trout.

\section{MATERIALS AND METHODS}

\subsection{Study System}

Jordanelle Reservoir is a manmade impoundment on the Provo River located in Wasatch County, Utah, USA. With the completion of Jordanelle dam in 1992, the reservoir began filling. The reservoir sits at an elevation of $1,880 \mathrm{~m}$ and has a surface area of $13.35 \mathrm{~km}^{2}$. The reservoir has been continuously stocked with fish since 1993 [35]. Native fish species in the reservoir are cutthroat trout (Oncorhynchus clarki), Utah chub (Gila atraria), and Utah sucker (Catostomus ardens). Non-native fish species in the reservoir are rainbow trout, brown trout, smallmouth bass, and yellow perch (Perca flavescens).

\subsection{Sample Collection}

We sampled fish throughout the reservoir in spring and summer of 2015 using angling, gill nets and electrofishing (locations in Fig. 1); sample numbers in Table 1. We sampled with gill nets at 8 locations in the reservoir. Gill nets were set shortly before dusk and retrieved shortly after dawn to include two crepuscular periods. Using an electrofishing 
boat, we sampled 4 transects in the reservoir, with each transect sampled for 20 minutes. We removed a $1 \mathrm{~cm}^{2}$ tissue sample from the epaxial muscle of each fish and recorded the total length of the fish. We used a $63 \mu \mathrm{m}$ plankton tow sampler to collect a sample from the water column and a sample from the water surface at three locations in the reservoir in June 2015 (locations in Fig. 1). We collected four samples of attached filamentous algae by hand near the shore in May 2015 (location in Fig. 1). We kept all samples frozen until lab preparation was commenced.

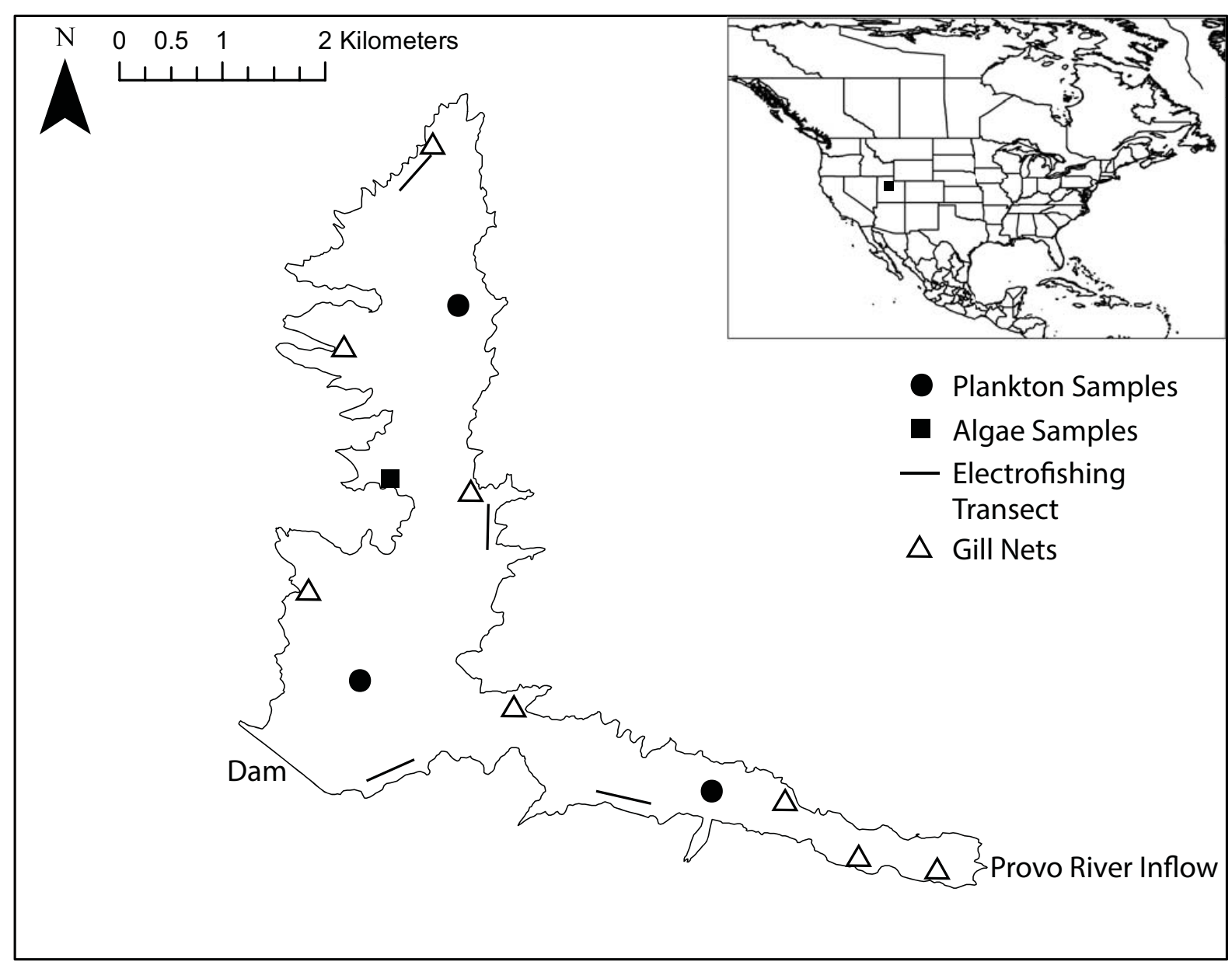

Fig. (1). Map of Jordanelle Reservoir, Utah, USA, showing dam, major inflow, and collection points for fish, plankton, and algae samples.

\subsection{Sample Preparation and Isotopic Analysis}

We oven-dried tissue samples at $60^{\circ} \mathrm{C}$ for 72 hours, ground the samples into a homogeneous powder with a mortar and pestle, and measured $0.6-1.2 \mathrm{mg}$ of the powder into small tin capsules. We sent the capsules to the Colorado Plateau Stable Isotope Laboratory at Northern Arizona University in Flagstaff, Arizona for stable isotope analysis. The analysis was carried out on a Delta V Advantage Mass Spectrometer (Thermo Electron Corporation, Bremen, Germany) configured through a CONFLO III (Thermo Electron Corporation), using a Carlo Erba NC2100 Elemental Analyzer (Thermo-Quest Italia S.p.A., Milano, Italy). We used delta notation $\left(\delta^{13} \mathrm{C}\right.$ and $\left.\delta^{15} \mathrm{~N}\right)$ expressed in parts per thousand (\%o) for the stable isotope values. The ratio of the stable isotope in the sample is compared to the ratio in international standards (Vienna Pee Dee Belemnite for carbon and atmospheric nitrogen standard for nitrogen) by the following equation: $\delta^{13} \mathrm{C}$ or $\delta^{15} \mathrm{~N}=\left[\left(\mathrm{R}_{\text {sample }} / \mathrm{R}_{\text {standard }}\right)-1\right] \times 1000$, where $\mathrm{R}$ is the ratio of ${ }^{13} \mathrm{C} /{ }^{12} \mathrm{C}$ or ${ }^{15} \mathrm{~N} /{ }^{14} \mathrm{~N}$. We calculated the trophic level by using the following equation: Trophic position $=\left[\left(\delta^{15} \mathrm{~N}_{\text {consumer }}-\delta^{15} \mathrm{~N}_{\text {algae }}\right) / 2.9\right]+1$, where $\delta^{15} \mathrm{~N}_{\text {consumer }}$ is the average signature of the organisms in question, $\delta^{15} \mathrm{~N}_{\text {algae }}$ is the average signature for algae, 2.9 is the enrichment factor for one trophic level [36], and one is added to account for the trophic level of the algae.

To determine whether isotope signatures of fish species varied with length, we performed linear regressions 
between $\delta^{15} \mathrm{~N}$ and total length and $\delta^{13} \mathrm{C}$ and total length for each species of fish (with the exception of Utah sucker, because all individuals of this species were large adults). For species that showed a significant relationship in the regression, we investigated further by splitting them into $100 \mathrm{~mm}$ size classes (e.g. 0-100 mm, 100-200 mm, 200-300 $\mathrm{mm}$, etc.) and performing ANOVA analyses followed by a Tukey HSD on these size classes to find statistical differences to separate species into size groups. For analysis and graphical presentation, we separated species-size groups that showed significant differences in isotopic signatures (either in $\delta^{15} \mathrm{~N}$ or $\delta^{13} \mathrm{C}$ ) from other groups of the same species. Based on this analysis, we divided all species, except Utah sucker, into two size-based groups as follows. Rainbow trout and brown trout: small $<400 \mathrm{~mm}$ TL (total length), and large $>400 \mathrm{~mm}$ TL (we captured only three large rainbow trout); smallmouth bass and Utah chub: small $<200 \mathrm{~mm} \mathrm{TL}$, and large $>200 \mathrm{~mm}$ TL (we captured only one small Utah chub); yellow perch: small $<100 \mathrm{~mm}$ TL, and large $>100 \mathrm{~mm}$ TL.

\subsection{Trophic Niche Analysis}

To calculate the niche space occupied by each fish species and overlap with small rainbow trout, we used the program Stable Isotope Bayesian Ellipse in R (SIBER) [37]. This program uses a maximum likelihood function based on the variance and covariance of the stable isotope signatures to construct ellipses that encompass roughly $40 \%$ of each included species data points, which is intended to represent the core niche of a species. We then calculated the overlap of this core niche area between small rainbow trout and other species. We used the $\mathrm{R}$ statistics package to perform all statistical analyses [38].

Table 1. Sample sizes and stable isotope ratios (mean \pm confidence interval) of fish species, algae, and plankton collected in Jordanelle Reservoir, Utah, USA.

\begin{tabular}{|l|c|c|c|}
\hline Species & $\boldsymbol{n}$ & $\boldsymbol{\delta}^{\mathbf{1 3}} \mathbf{C}$ & $\boldsymbol{\delta}^{\mathbf{1 5}} \mathbf{N}$ \\
\hline brown trout (large, $>400 \mathrm{~mm})$ & 12 & $-28.14 \pm 0.97$ & $14.47 \pm 0.44$ \\
\hline brown trout (small, $<400 \mathrm{~mm})$ & 8 & $-28.56 \pm 0.54$ & $13.05 \pm 0.65$ \\
\hline rainbow trout (large, $>400 \mathrm{~mm})$ & 3 & $-30.84 \pm 0.75$ & $15.69 \pm 0.62$ \\
\hline rainbow trout (small, $<400 \mathrm{~mm})$ & 23 & $-29.15 \pm 0.55$ & $13.59 \pm 0.17$ \\
\hline Utah chub (large, $>200 \mathrm{~mm})$ & 28 & $-31.16 \pm 0.48$ & $12.25 \pm 0.30$ \\
\hline Utah chub (small, $<200 \mathrm{~mm}$ ) & 1 & -25.24 & 10.76 \\
\hline Utah Sucker & 9 & $-27.92 \pm 0.90$ & $11.54 \pm 0.27$ \\
\hline Smallmouth bass (large, $>200 \mathrm{~mm})$ & 26 & $-28.01 \pm 0.27$ & $14.58 \pm 0.23$ \\
\hline smallmouth bass (small, $<200 \mathrm{~mm})$ & 14 & $-27.93 \pm 0.48$ & $13.32 \pm 0.45$ \\
\hline yellow perch (large, $>100 \mathrm{~mm})$ & 13 & $-27.89 \pm 0.41$ & $12.85 \pm 0.32$ \\
\hline yellow perch (small, $<100 \mathrm{~mm})$ & 15 & $-29.19 \pm 0.23$ & $6.09 \pm 1.00$ \\
\hline algae & 4 & $-26.99 \pm 0.30$ & $6.79 \pm 0.85$ \\
\hline plankton & 5 & $-32.19 \pm 0.59$ & \\
\hline
\end{tabular}

\section{RESULTS}

\subsection{Food Web Structure}

As expected, trophic position varied widely among organisms in the food web Fig. (2). Algae was positioned at the base of the food web (trophic level 1), consistent with its place as primary producers. Plankton was near the base of the food web indicating a composition of plankton samples dominated by phytoplankton (trophic level 1.2). Utah sucker and Utah chub occupied the lowest trophic levels among the fish (2.8 to 3.1). Small brown trout and both size classes of yellow perch occupied the next trophic levels (3.3 to 3.4). Small rainbow trout, large brown trout, and smallmouth bass occupied slightly higher trophic levels (3.6 to 3.9). Large rainbow trout occupied the highest trophic level (trophic level 4.3).

Jordanelle reservoir exhibited littoral and pelagic energy pathways, and these two pathways converged somewhat at the level of top predators Fig. (2). The base of the littoral energy pathway was occupied by algae (enriched in $\delta^{13} \mathrm{C}$ ). The base of the pelagic pathway was occupied by plankton (depleted in $\delta^{13} \mathrm{C}$ ). Fish were positioned somewhat intermediate between the littoral and pelagic pathways. Utah sucker had the highest dependence (enriched in $\delta^{13} \mathrm{C}$ ) on the littoral energy pathway among fish, followed by smallmouth bass, brown trout and yellow perch, respectively. Small rainbow trout exhibited a slightly higher dependence on the pelagic energy pathway, while Utah chub and large rainbow trout had the highest dependence on the pelagic energy pathway among fish (least enriched $\delta^{13} \mathrm{C}$ ). 


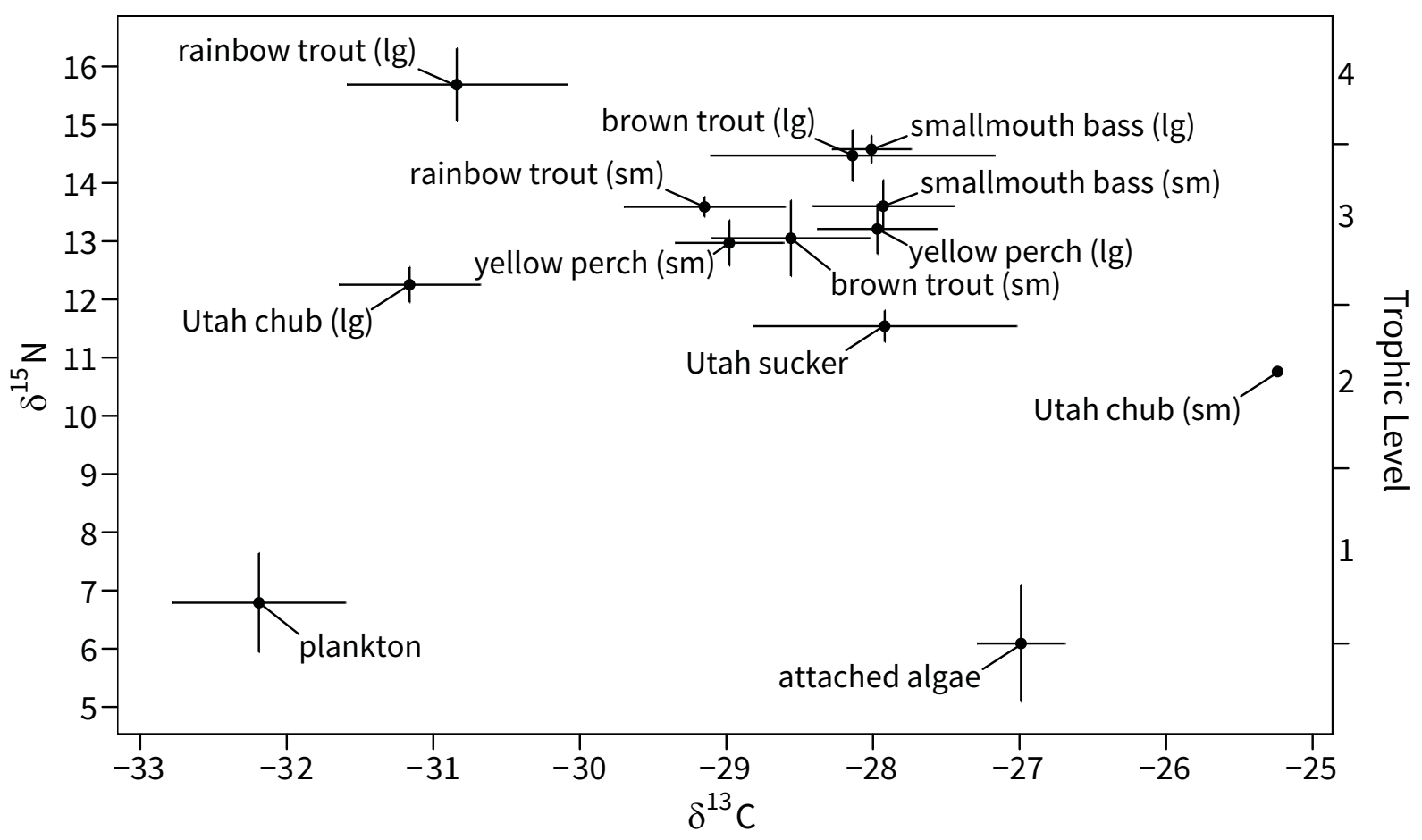

Fig. (2). Bi-plot of average $\delta^{13} \mathrm{C}$ and $\delta^{15} \mathrm{~N}$ signatures of all fish species, algae, and plankton in Jordanelle Reservoir, Utah, USA. Error bars represent confidence intervals.

\subsection{Trophic Niche Analysis}

The core isotopic niche of small rainbow trout overlapped substantially with four other species-size groups as follows: $38.4 \%$ with small yellow perch, $38.1 \%$ with small brown trout, $31.6 \%$ with small smallmouth bass, $25.6 \%$ with large yellow perch, and $2.5 \%$ with large brown trout. The core niche of small rainbow trout did not overlap with large rainbow trout, large smallmouth bass, or Utah chub (Fig. 3).

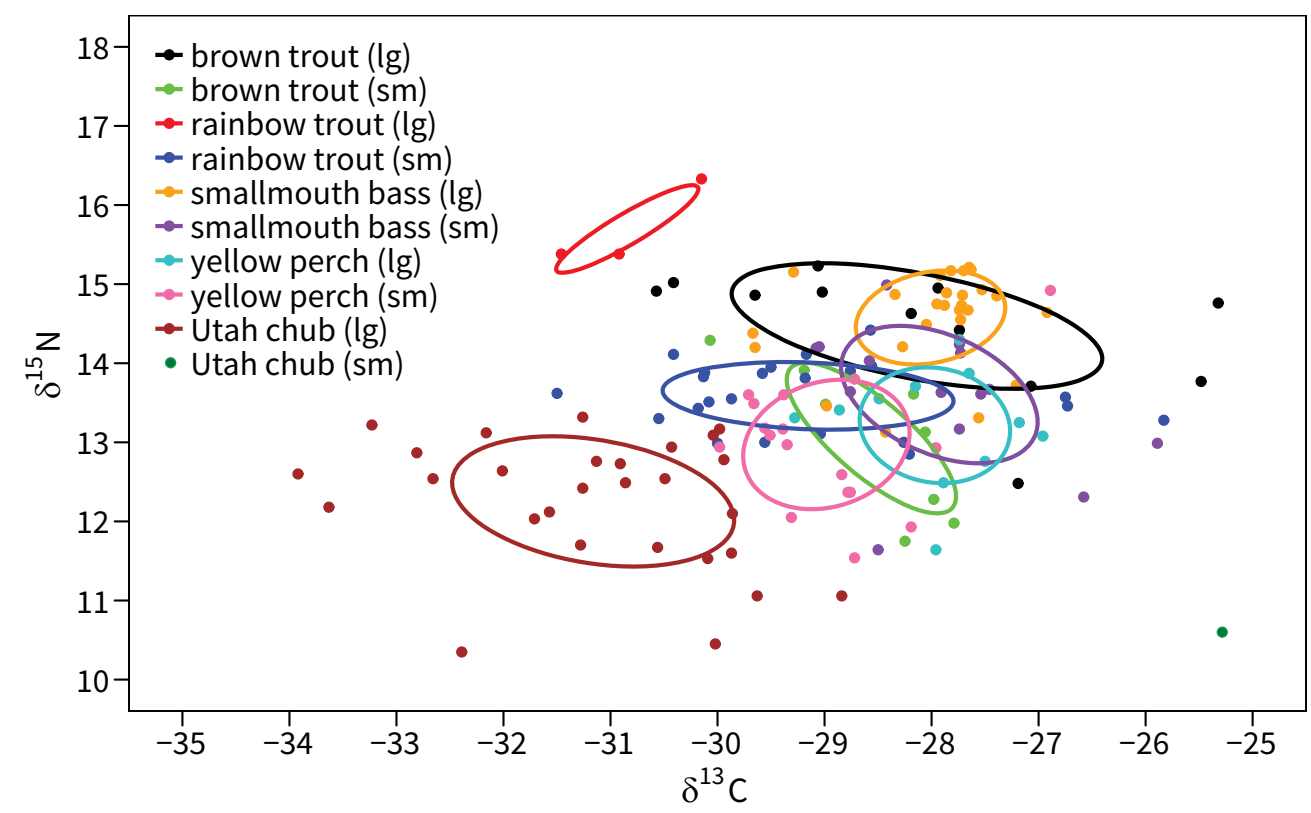

Fig. (3). Core isotopic niche ellipses and niche overlap from SIBER analysis for two size classes of five species of fish from Jordanelle Reservoir, Utah, USA. 


\section{DISCUSSION}

We show strong evidence for competition between small rainbow trout and other fish in Jordanelle reservoir. The core niche of small rainbow trout overlapped moderately with small size classes of brown trout and smallmouth bass and with both size classes of yellow perch. Overall, more than half of the core niche of small rainbow trout is overlapped by a combination of these fish. The niche space around the small rainbow trout appears to be crowded with brown trout, smallmouth bass, and yellow perch. The core niche of small rainbow trout was slightly more depleted in $\delta^{13} \mathrm{C}$ than the other fish with which it overlapped, suggesting a slightly higher dependence on pelagic food sources, which has been observed in other systems [39 - 41]. Competition with other fish species may account for the slightly more pelagic diet of small rainbow trout. Brown trout have displaced rainbow trout in other systems and smallmouth bass and yellow perch have impacted other salmonids by displacing them from the littoral energy pathway into the pelagic energy pathway [42 - 44]. However, in Jordanelle reservoir, Utah chub are the most abundant fish in the reservoir, and they may be monopolizing the pelagic energy sources (i.e., zooplankton) [24]. As such, small rainbow trout appear to be inhabiting a highly competitive environment between brown trout, smallmouth bass, and yellow perch in the littoral energy pathway and Utah chub in the pelagic energy pathway. High levels of competition with other species could contribute to the poor return of rainbow trout in this system.

Large brown trout and large smallmouth bass attain sizes in Jordanelle reservoir that allow them to prey upon the smaller size classes of rainbow trout, which could create a strong top-down effect. Hatchery-reared fish are often predator naïve and are highly susceptible to predation because they often lack antipredator responses [45]. In an attempt to reduce predation on newly stocked rainbow trout, the Utah Division of Wildlife Resources stocks rainbow trout at sizes larger than $200 \mathrm{~mm}$. However, our samples included several brown trout over $500 \mathrm{~mm}$ and a few smallmouth basses over $350 \mathrm{~mm}$, which would possess a gape size large enough to prey upon stocked rainbow trout [40, 46]. In addition, some rainbow trout exceeded $400 \mathrm{~mm}$ and were large enough to prey upon stocked rainbow trout. Furthermore, the position of large brown trout and large smallmouth bass in the food web suggests that these species likely prey heavily on small rainbow trout and other small fishes that have similar isotopic signatures as small rainbow trout (i.e., yellow perch, small brown trout, and small smallmouth bass). High levels of predation from large piscivores could contribute to the poor return of rainbow trout in this system.

The few rainbow trout that survive and grow to large size in Jordanelle reservoir appear to exhibit an ontogenetic niche shift at around $400 \mathrm{~mm}$ when they begin to feed at a higher trophic level that is also farther toward the pelagic energy pathway than small rainbow trout. Often, such shifts at larger body sizes coincide with a switch to piscivory [47], and these large individuals had the highest trophic signature of all fish sampled. The core niche of large rainbow trout did not overlap with any other species. However, this core niche is only based on three individuals and the size of the core niche is likely underestimated. Nevertheless, these fish were grouped tightly and distinctly from all other species in our sampling, suggesting a diet switch to an area of trophic niche space that is unoccupied by other fish in the reservoir.

\section{CONCLUSION}

We show evidence for the possibility of both bottom-up and top-down effects on rainbow trout in Jordanelle reservoir. Due to the dual nature of threats to small rainbow trout (i.e., competition and predation), it seems unlikely that stocking different species of sports fish would alleviate the problem of low survival of rainbow trout. Rainbow trout survival will probably remain low unless the composition of the food web changes dramatically to alleviate either competitive or predatory interactions indicated by this analysis.

\section{ETHICS APPROVAL AND CONSENT TO PARTICIPATE}

Not applicable.

\section{HUMAN AND ANIMAL RIGHTS}

Samples were collected under direction of the Utah Division of Wildlife Resources. All sampling was conducted in accordance with the American Fisheries Society Guidelines for the Use of Fishes in Research.

\section{CONSENT FOR PUBLICATION}

Not applicable. 


\section{CONFLICT OF INTEREST}

The authors declare that they have no conflict of interest. This project was funded by the Utah Division of Wildlife Resources (UDWR).

\section{ACKNOWLEDGEMENTS}

All fish samples were collected under the direction of the Utah Division of Wildlife Resources. We would like to thank M. Slater, D. Wiley, and J. Watson from the UDWR for providing reports and assistance with collecting samples. Funding was provided by UDWR. We thank A. Brooksby, D. Shirley, S. Smith, W. Gleave, J. DeMordaunt, A. DeVries, A. Jensen, and D. Chambers who helped with the collection and processing of samples.

\section{REFERENCES}

[1] Matthews WJ, Gido KB, Gelwick FP. Fish assemblages of reservoirs, illustrated by Lake Texoma (Oklahoma-Texas, USA) as a representative system. Lake Reserv Manage 2004; 20: 219-39.

[http://dx.doi.org/10.1080/07438140409354246]

[2] Miranda LE. A typology of fisheries in large reservoirs of the United States. N Am J Fish Manage 1999; $19: 536-50$. [http://dx.doi.org/10.1577/1548-8675(1999)019<0536:ATOFIL >2.0.CO;2]

[3] Moyle PB. Fish introductions into North America: Patterns and ecological impact.Ecology of Biological Invasions of North America and Hawaii. New York, NY: Springer New York 1986; pp. 27-43. [http://dx.doi.org/10.1007/978-1-4612-4988-7_2]

[4] Rahel FJ. Homogenization of fish faunas across the United States. Science 2000; 288(5467): 854-6. [http://dx.doi.org/10.1126/science.288.5467.854] [PMID: 10797007]

[5] Rahel FJ. Homogenization of freshwater faunas. Annu Rev Ecol Syst 2002; 33: 291-315. [http://dx.doi.org/10.1146/annurev.ecolsys.33.010802.150429]

[6] Wydoski RS, Bennett DH. Forage species in lakes and reservoirs of the western United States. Trans Am Fish Soc 1981; 110 : 764-71. [http://dx.doi.org/10.1577/1548-8659(1981)110<764:FSILAR>2.0.CO;2]

[7] Noble RL. Predator-prey interactions in reservoir communities.Reservoir fisheries management: Strategies for the 80's. Bethesda, Maryland: American Fisheries Society 1986; pp. 137-43.

[8] Stein RA, DeVries DR, Dettmers JM. Food-web regulation by a planktivore: Exploring the generality of the trophic cascade hypothesis. Can J Fish Aquat Sci 1995; 52: 2518-26. [http://dx.doi.org/10.1139/f95-842]

[9] Persson L, Byström P, Wahlström E, Andersson J, Hjelm J. Interactions among size-structured populations in a whole-lake experiment: Sizeand scale-dependent processes. Oikos 1999; 87: 139-56. [http://dx.doi.org/10.2307/3547005]

[10] Wilbur HM. Interactions between growing predators and growing prey.Size-structured populations: Ecology and evolution. Berlin, Heidelberg: Springer berlin heidelberg 1988; pp. 157-72. [http://dx.doi.org/10.1007/978-3-642-74001-5_11]

[11] Werner EE, Gilliam JF. The ontogenetic niche and species interactions in size-structured populations. Annu Rev Ecol Syst 1984; 15 : $393-425$. [http://dx.doi.org/10.1146/annurev.es.15.110184.002141]

[12] Holt RD, Polis GA. A theoretical framework for intraguild predation. Am Nat 1997; 149: 745-64. [http://dx.doi.org/10.1086/286018]

[13] Ruzycki JR, Wurtsbaugh WA, Luecke C. Salmonine consumption and competition for endemic prey fishes in bear lake, utah- idaho. Trans Am Fish Soc 2001; 130: 1175-89. [http://dx.doi.org/10.1577/1548-8659(2001)130<1175:SCACFE $>2.0 . C O ; 2]$

[14] Carpenter SR, Kitchell JF. Consumer Control of Lake Productivity. Bioscience 1988; 38: 764-9. [http://dx.doi.org/10.2307/1310785]

[15] McQueen DJ, Post JR, Mills EL. Trophic Relationships in Freshwater Pelagic Ecosystems. Can J Fish Aquat Sci 1986; 43: 1571-81. [http://dx.doi.org/10.1139/f86-195]

[16] Jeppesen E, Jensen JP, Jensen C, Faafeng B, Hessen DO, Søndergaard M, et al. The impact of nutrient state and lake depth on top-down control in the pelagic zone of lakes: A study of 466 lakes from the temperate zone to the arctic. Ecosystems (N Y) 2003; 6: 313-25. [http://dx.doi.org/10.1007/PL00021503]

[17] Eby LA, Roach WJ, Crowder LB, Stanford JA. Effects of stocking-up freshwater food webs. Trends Ecol Evol (Amst) 2006; 21(10): 576-84 [http://dx.doi.org/10.1016/j.tree.2006.06.016] [PMID: 16828522]

[18] McQueen DJ, Johannes MRS, Post JR, Stewart TJ, Lean DRS. Bottom Up and Top Down Impacts on Freshwater Pelagic Community 
Structure. Ecol Monogr 1989; 59: 289-309.

[http://dx.doi.org/10.2307/1942603]

[19] Hunter MD, Price PW. Playing Chutes and Ladders: Heterogeneity and the Relative Roles of Bottom-Up and Top-Down Forces in Natural Communities. Ecology 1992; 73: 724-32.

[20] Rosemond AD, Mulholland PJ, Elwood JW. Top-Down and Bottom-Up Control of Stream Periphyton: Effects of Nutrients and Herbivores. Ecology 1993; 74: 1264-80.

[http://dx.doi.org/10.2307/1940495]

[21] Crawford SS, Muir AM. Global introductions of salmon and trout in the genus Oncorhynchus: 1870-2007. Rev Fish Biol Fish 2008; 18: 313-44. [http://dx.doi.org/10.1007/s11160-007-9079-1]

[22] Nielson J, Wiley DE. Jordanelle Reservoir: Magagment status report and discussion 2011. Salt Lake City, Utah: Utah Department of Natural Resources 2011.

[23] Kimmel BL, Groeger AW. Limnological and ecological changes associated with reservoir aging. In: American Fisheries Society symposium on reservoir fisheries management Lexington; 14 June; Kentucky. 1983; pp. 1-23.

[24] Watson J, Wiley DE, Slater M. Jordanelle Reservoir fall 2015 field report. Salt Lake City, Utah: Utah Department of Natural Resources 2015.

[25] Layman CA, Araujo MS, Boucek R, et al. Applying stable isotopes to examine food-web structure: An overview of analytical tools. Biol Rev Camb Philos Soc 2012; 87(3): 545-62.

[http://dx.doi.org/10.1111/j.1469-185X.2011.00208.x] [PMID: 22051097]

[26] Post DM. Using stable isotopes to estimate trophic position: Models, methods, and assumptions. Ecology 2002; 83: 703-18. [http://dx.doi.org/10.1890/0012-9658(2002)083[0703:USITET]2.0.CO;2]

[27] DeNiro MJ, Epstein S. Influence of diet on the distribution of nitrogen isotopes in animals. Geochim Cosmochim Acta 1981; 45: 341-51. [http://dx.doi.org/10.1016/0016-7037(81)90244-1]

[28] Minagawa M, Wada E. Stepwise enrichment of $15 \mathrm{~N}$ along food chains: Further evidence and the relation between $\delta 15 \mathrm{~N}$ and animal age. Geochim Cosmochim Acta 1984; 48: 1135-40

[http://dx.doi.org/10.1016/0016-7037(84)90204-7]

[29] Peterson BJ, Fry B. Stable isotopes in ecosystem studies. Annu Rev Ecol Syst 1987; 18: 293-320. [http://dx.doi.org/10.1146/annurev.es.18.110187.001453]

[30] Layman CA, Arrington DA, Montaña CG, Post DM. Can stable isotope ratios provide for community-wide measures of trophic structure? Ecology 2007; 88(1): 42-8.

[http://dx.doi.org/10.1890/0012-9658(2007)88[42:CSIRPF]2.0.CO;2] [PMID: 17489452]

[31] Rounick JS, Winterbourn MJ. Stable carbon isotopes and carbon flow in ecosystems. Bioscience 1986; $36: 171-7$. [http://dx.doi.org/10.2307/1310304]

[32] France RL, Peters RH. Ecosystem differences in the trophic enrichment of 13C in aquatic food webs. Can J Fish Aquat Sci 1997; 54: 1255-8. [http://dx.doi.org/10.1139/f97-044]

[33] DeNiro MJ, Epstein S. Influence of diet on the distribution of carbon isotopes in animals. Geochim Cosmochim Acta 1978; 42 : 495-506. [http://dx.doi.org/10.1016/0016-7037(78)90199-0]

[34] France RL. Differentiation between littoral and pelagic food webs in lakes using stable carbon isotopes. Limnol Oceanogr 1995 ; 40 : 1310-3. [http://dx.doi.org/10.4319/1o.1995.40.7.1310]

[35] Hepworth RD, Wiley DE. Jordanelle reservoir fish population monitoring 1993-2004. Salt Lake City, Utah: Utah Department of Natural Resources 2005.

[36] McCutchan JH, Lewis WM, Kendall C, McGrath CC. Variation in trophic shift for stable isotope ratios of carbon, nitrogen, and sulfur. Oikos 2003; 102: 378-90. [http://dx.doi.org/10.1034/j.1600-0706.2003.12098.x]

[37] Jackson AL, Inger R, Parnell AC, Bearhop S. Comparing isotopic niche widths among and within communities: SIBER - Stable Isotope Bayesian Ellipses in R. J Anim Ecol 2011; 80(3): 595-602. [http://dx.doi.org/10.1111/j.1365-2656.2011.01806.x] [PMID: 21401589]

[38] R: A language and environment for statistical computing. Vienna, Austria: R Foundation for Statistical Computing 2016.

[39] Christensen DR, Moore BC. Using stable isotopes and a multiple-source mixing model to evaluate fish dietary niches in a mesotrophic lake. Lake Reserv Manage 2009; 25: 167-75. [http://dx.doi.org/10.1080/07438140902905588]

[40] Winters LK, Budy P. Exploring crowded trophic niche space in a novel reservoir fish assemblage: How many is too many? Trans Am Fish Soc 2015; 144: 1117-28. [http://dx.doi.org/10.1080/00028487.2015.1083475]

[41] Tabor R, Luecke C, Wurtsbaugh W. Effects of daphnia availability on growth and food consumption of rainbow trout in two Utah reservoirs. N Am J Fish Manage 1996; 16: 591-9. [http://dx.doi.org/10.1577/1548-8675(1996)016<0591:EODAOG>2.3.CO;2] 
[42] Gatz AJ Jr, Sale MJ, Loar JM. Habitat shifts in rainbow trout: Competitive influences of brown trout. Oecologia 1987; 74(1): 7-19. [http://dx.doi.org/10.1007/BF00377339] [PMID: 28310408]

[43] Vander Zanden MJ, Casselman JM, Rasmussen JB. Stable isotope evidence for the food web consequences of species invasions in lakes. Nature 1999; 401: 464-7.

[http://dx.doi.org/10.1038/46762]

[44] Browne DR, Rasmussen JB. Shifts in the trophic ecology of brook trout resulting from interactions with yellow perch: An intraguild predatorprey interaction. Trans Am Fish Soc 2009; 138: 1109-22. [http://dx.doi.org/10.1577/T08-113.1]

[45] Brown GE, Smith RJF. Acquired predator recognition in juvenile rainbow trout (Oncorhynchus mykiss): Conditioning hatchery-reared fish to recognize chemical cues of a predator. Can J Fish Aquat Sci 1998; 55: 611-7. [http://dx.doi.org/10.1139/f97-261]

[46] Mittelbach GG, Persson L. The ontogeny of piscivory and its ecological consequences. Can J Fish Aquat Sci 1998; 55: 1454-65. [http://dx.doi.org/10.1139/f98-041]

[47] Clarke LR, Vidergar DT, Bennett DH. Stable isotopes and gut content show diet overlap among native and introduced piscivores in a large oligotrophic lake. Ecol Freshwat Fish 2005; 14: 267-77. [http://dx.doi.org/10.1111/j.1600-0633.2005.00103.x]

(C) 2018 Verde and Belk.

This is an open access article distributed under the terms of the Creative Commons Attribution 4.0 International Public License (CC-BY 4.0), a copy of which is available at: (https://creativecommons.org/licenses/by/4.0/legalcode). This license permits unrestricted use, distribution, and reproduction in any medium, provided the original author and source are credited. 